Marquette University

e-Publications@Marquette

Chemistry Faculty Research and Publications

Chemistry, Department of

$1-1-2010$

Isomerization as a Key Path to Molecular Products in the Gas-Phase Decomposition of Halons

Aimable Kalume

Marquette University, aimable.kalume@marquette.edu

Lisa George

Marquette University

Scott Reid

Marquette University, scott.reid@marquette.edu

Accepted version. Journal of Physical Chemistry Letters, Vol. 1, No. 20 (2010): 3090-3095. DOI. (C) 2010 American Chemical Society. Used with permission. 


\title{
Isomerization as a Key Path to Molecular Products in the Gas-Phase Decomposition of Halons
}

\author{
Aimable Kalume \\ Department of Chemistry, Marquette University, Milwaukee, WI \\ Lisa George \\ Department of Chemistry, Marquette University, Milwaukee, WI \\ Scott A. Reid \\ Department of Chemistry, Marquette University, Milwaukee, WI
}

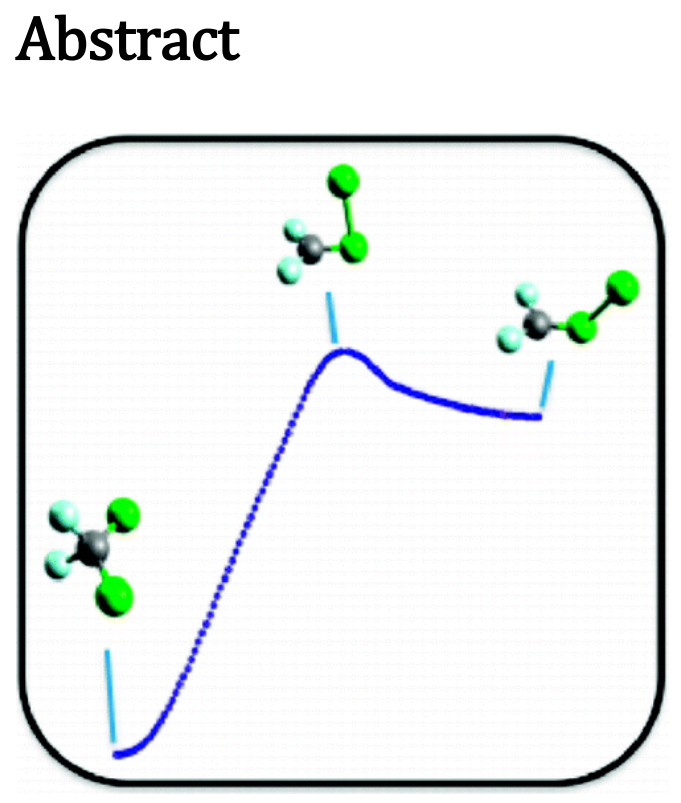

Journal of Physical Chemistry Letters, Vol. 1, No. 20 (2010): pg. 3090-3095. DOI. This article is @ American Chemical Society and permission has been granted for this version to appear in e-Publications@Marquette. American Chemical Society does not grant permission for this article to be further copied/distributed or hosted elsewhere without the express permission from American Chemical Society. 
The decomposition of halons remains controversial concerning the branching between radical and molecular products. The latter channel, where it has been found, is presumed to occur via a constrained symmetric multicenter transition state. Isomerization pathways in the gas-phase chemistry of halons have rarely been considered, despite the fact that the iso-halons, which feature a halogen-halogen bond, are widely recognized as important reactive intermediates in condensed phases. In this Letter, detailed calculations and modeling of the unimolecular decomposition of several important halons, including $\mathrm{CF}_{2} \mathrm{Cl}_{2}, \mathrm{CF}_{2} \mathrm{Br}_{2}$, and $\mathrm{CHBr}_{3}$, reveal that isomerization is a key pathway to molecular products. This path is important for both halons and their primary radicals as the barrier to isomerization in these compounds is typically isoenergetic with the threshold for bond fission.

Keywords: decomposition; halocarbons; iso-halomethanes; isomerization

Halocarbons such as chlorofluorocarbons (CFCs) are famous for their role in ozone depletion, 1 and due to their past widespread industrial use, it is crucial to understand the pathways for their decomposition. Perhaps surprisingly, the decomposition of simple halons such as $\mathrm{CF}_{2} \mathrm{Cl}_{2}, \mathrm{CF}_{2} \mathrm{Br}_{2}$, and $\mathrm{CHBr}_{3}$ remains controversial concerning the branching between radical and molecular products. The latter channel, where it has been found, is usually assumed to involve a constrained symmetric multicenter transition state, which has not been identified computationally. $\underline{2}$ The iso-halons are well-known condensed-phase reactive intermediates that possess a halogen-halogen bond; $\underline{3-15}$ yet, few studies have suggested a role for these species in the gas-phase chemistry of halons. In recent studies of the multiphoton dissociation of the halons $\mathrm{CHX}_{3}$ and $\mathrm{CX}_{4},(\mathrm{X}=\mathrm{Br}, \mathrm{I})$, Quandt and coworkers suggested on the basis of secondary evidence a mechanism that involved the isospecies. $\frac{16,17}{17}$ However, to date, conclusive evidence has not been provided for the role of isomerization in the thermal or photoinitiated decomposition of halons.

Our interest in this topic began in recent studies of the spectroscopy and photochemistry of the weakly bound iso- $\mathrm{CF}_{2} \mathrm{X}_{2}(\mathrm{X}=\mathrm{Br}, \mathrm{I})$ species, which were trapped in $\mathrm{Ar}$ and Ne matrixes at $5 \mathrm{~K} . \underline{18,19}$ Excitation into the intense near-UV band of iso- $\mathrm{CF}_{2} \mathrm{Br}_{2}$ resulted in back-isomerization to $\mathrm{CF}_{2} \mathrm{Br}_{2}, \underline{19}$ and intrinsic reaction coordinate (IRC) calculations showed that a first-order saddle point connects the two minima. We have explored what relevance this isomerization might hold for the gas-phase chemistry of halons, and in this Letter, we show through detailed calculations and modeling that isomerization is a key pathway to molecular products in the gas-phase decomposition of halons. This finding is of general utility as the isomerization barrier in halons and their primary radicals is typically isoenergetic with the threshold for simple bond fission.

Journal of Physical Chemistry Letters, Vol. 1, No. 20 (2010): pg. 3090-3095. DOI. This article is @ American Chemical Society and permission has been granted for this version to appear in e-Publications@Marquette. American Chemical Society does not grant permission for this article to be further copied/distributed or hosted elsewhere without the express permission from American Chemical Society. 
The thermal decomposition of $\mathrm{CF}_{2} \mathrm{Cl}_{2}$ (Halon 122 or $\mathrm{CFC}-12$ ) has been wellstudied; $; 2$ 20-25 however, in our opinion, the seminal experiment with respect to the existence of a molecular channel was reported in 1982 by Y. T. Lee and co-workers, who examined the infrared multiphoton dissociation (IRMPD) of $\mathrm{CF}_{2} \mathrm{Cl}_{2}$ under collision-free conditions in a molecular beam using a universal mass spectrometric detection. $\underline{21}$ Two different reaction channels were observed, (i) a radical channel forming $\mathrm{CF}_{2} \mathrm{Cl}+\mathrm{Cl}$ and (ii) a molecular channel forming $\mathrm{CF}_{2}+\mathrm{Cl}_{2}$. The energetic thresholds of these channels were determined to be equal $(80 \mathrm{kcal} / \mathrm{mol})$ to within the experimental precision of $\pm 4 \mathrm{kcal} / \mathrm{mol}$, and at the estimated average internal energy of $88 \mathrm{kcal} / \mathrm{mol}$, the yield of the molecular channel was $\sim 10 \%$. This was consistent with earlier IRMPD studies that reported yields of 3-15\%. 20,24 It was assumed in this work that the molecular channel proceeded via a symmetric three-center transition state (TS); however, we will show that all of these findings are consistent with isomerization as the pathway to molecular products. $\underline{26}$

We began by examining stationary points on the $\mathrm{CF}_{2} \mathrm{Cl}_{2}$ potential energy surface (PES). The structures of all relevant species, including $\mathrm{CF}_{2} \mathrm{Cl}_{2}$, iso- $\mathrm{CF}_{2} \mathrm{Cl}_{2}$, the isomerization transition state, $\mathrm{CF}_{2}, \mathrm{Cl}_{2}$, and $\mathrm{CF}_{2} \mathrm{Cl}$, were optimized at the MP2/aug-cc-pVTZ level. Spinunrestricted wave functions were used for open-shell species, and vibrational frequencies were calculated to ensure that stationary points corresponded to the expected minima (all real frequencies) or first-order saddle point (one imaginary frequency). The stability of the MP2 wave function for the isomerization transition state was tested, and the single determinant reference was found to be stable. Subsequently, single-point energy calculations on the MP2-optimized structures were performed at the CCSD(T)/aug-ccpVTZ level. The results of these calculations are shown in Figure 1 , and the geometries of all optimized structures are provided in Table 1S in the Supporting Information.

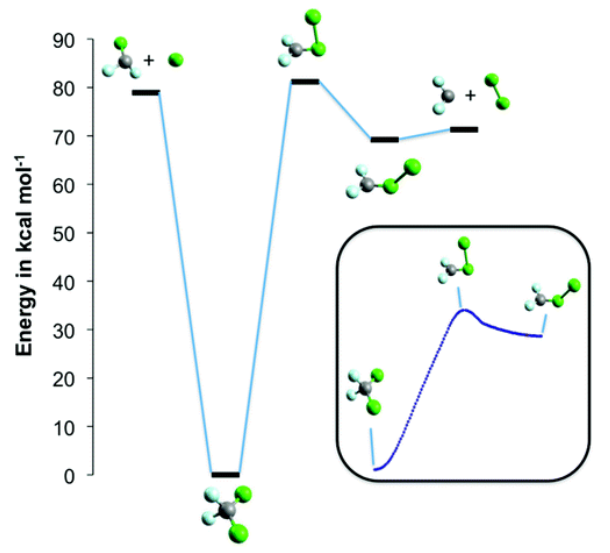

Figure 1. Stationary points (ZPE-corrected) on the $\mathrm{CF}_{2} \mathrm{C}_{2}$ potential energy surface, calculated at the CCSD(T)//MP2/aug-cc-pVTZ level. The inset shows an IRC scan which confirms that a first-order saddle point connects the two $\mathrm{CF}_{2} \mathrm{C}_{2}$ isomers.

Journal of Physical Chemistry Letters, Vol. 1, No. 20 (2010): pg. 3090-3095. DOI. This article is @ American Chemical Society and permission has been granted for this version to appear in e-Publications@Marquette. American Chemical Society does not grant permission for this article to be further copied/distributed or hosted elsewhere without the express permission from American Chemical Society. 
From Figure 1 , we see that the calculated threshold energies for the radical and molecular channels, 78.9 and $71.3 \mathrm{kcal} / \mathrm{mol}$, respectively, are in excellent agreement with literature values of 80 and $73 \mathrm{kcal} / \mathrm{mol} . \underline{21}$ In addition, the calculated energy of the isomerization transition state lies only $1.1 \mathrm{kcal} / \mathrm{mol}$ above the radical threshold, consistent with the result of Lee and co-workers, who found that the thresholds for radical and molecular channels were equal to within $4 \mathrm{kcal} / \mathrm{mol}$. IRC calculations at the MP2/aug-ccpVTZ level, shown as the inset in Figure 1 , confirm that the putative isomerization transition state connects the minima corresponding to the two isomeric forms of $\mathrm{CF}_{2} \mathrm{Cl}_{2}$. We emphasize that an extensive computational effort was made to locate a symmetric three-center transition state for the molecular channel; however, all attempts to locate this TS either failed to converge or converged to the isomerization transition-state structure shown in Figure 1. Similarly, Bacskay and co-workers attempted but failed to locate a firstorder saddle point for dihalogen elimination in $\mathrm{CF}_{2} \mathrm{X}_{2}(\mathrm{X}=\mathrm{Cl}, \mathrm{Br}) . \underline{2} \mathrm{~A}$ prior theoretical study had identified a barrier for elimination lying $\sim 38 \mathrm{kcal} / \mathrm{mol}$ above the radical threshold; $\underline{27}$ however, the order of that saddle point was not determined. We conclude that if a symmetric three-center TS for elimination exists, it must lie at higher energy.

We next modeled the relative reaction rates for the radical and molecular (isomerization) channels using microcanonical transition-state (RRKM) theory as implemented in the CHEMRATE program. $\underline{28}$ In the RRKM treatment, $\underline{29}$ the microcanonical rate constant at a given energy is represented by the expression

$$
k\left(E_{J} J\right)=\frac{1}{h} \frac{N\left(E-E_{0}\right)}{\rho\left(E_{0} J\right)}
$$

The numerator in eq 1 reflects the number of open channels at the transition state at a given energy above the critical reaction threshold $\left(E_{0}\right)$, and the denominator is the density of reactant states at that energy. Two different RRKM calculations were performed. In the first, the transition-state structure of the radical channel at the energies probed by Lee and co-workers was obtained by fixing one $\mathrm{C}-\mathrm{Cl}$ bond length at a critical distance, set at the top of the centrifugal barrier, and optimizing all other coordinates. The second calculation was based on a restricted-rotor Gorin model, $\underline{30,31}$ similar to that used in a study of the thermal decomposition of $\mathrm{CF}_{2} \mathrm{Cl}_{2} \cdot \underline{25}$ All MP2 vibrational frequencies were scaled by a factor of $0.96 ; \underline{32}$ full details of the input to the rate calculations are provided in Table $2 \mathrm{~S}$ in the Supporting Information. The upper panel of Figure $\underline{2}$ shows the calculated microcanonical rate constants $k(E)$ as a function of energy $\left(\mathrm{in} \mathrm{cm}^{-1}\right.$ ) for the radical and molecular channels from the first RRKM calculation, while the lower panel gives the energy dependence of the percent yield of molecular products. The rate constants derived for the

Journal of Physical Chemistry Letters, Vol. 1, No. 20 (2010): pg. 3090-3095. DOI. This article is @ American Chemical Society and permission has been granted for this version to appear in e-Publications@Marquette. American Chemical Society does not grant permission for this article to be further copied/distributed or hosted elsewhere without the express permission from American Chemical Society. 
molecular channel are, strictly speaking, for isomerization; however, the isomer, once formed, will not be stable with respect to dissociation via either $\mathrm{Cl}-\mathrm{Cl}$ or $\mathrm{C}-\mathrm{Cl}$ bond cleavage (Figure 1). Here, we assume a unit quantum yield for the formation of molecular products following isomerization, which should be a good approximation for energies near threshold (Figure 1 ); however, as a result, the yield of the molecular channel shown in Figure $\underline{2}$ is an upper limit.
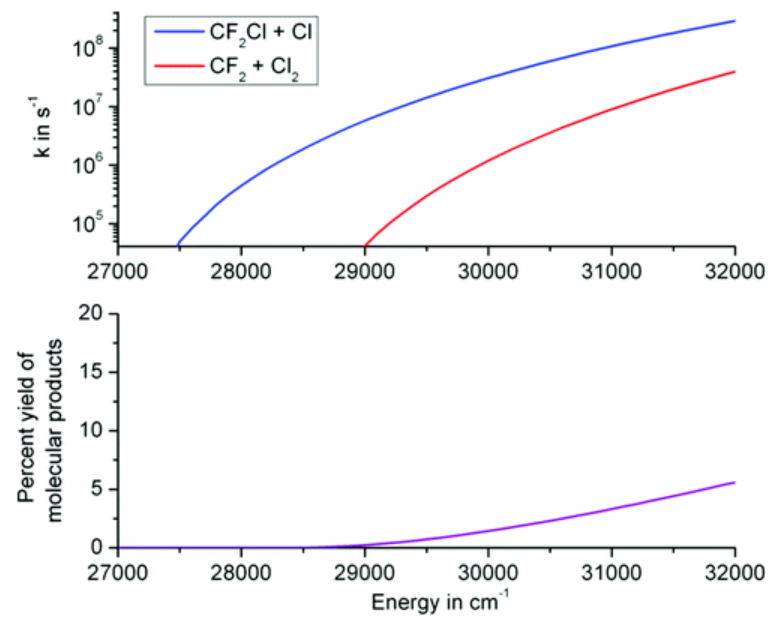

Figure 2. Upper panel: Calculated microscopic rate constants for $\mathrm{CF}_{2} \mathrm{C1}_{2}$ decomposition, as described in the text. Lower panel: Percent yield of the molecular channel as a function of energy.

It is seen from the top panel in Figure $\underline{2}$ that the radical channel dominates at all energies. At an energy characteristic of the estimated mean energy in the Lee experiments, $8 \mathrm{kcal} / \mathrm{mol}$ above the radical threshold or $30800 \mathrm{~cm}^{-1}$, the calculated yield of molecular products is $\sim 3 \%$, compared with the $10 \%$ experimental yield estimated by Lee and coworkers. Calculations using the second RRKM model gave a similar yield. While our estimate is low compared with that from the Lee experiment and on the lower end of the range suggested by the IRMPD studies, $\underline{20,24}$ we consider the level of agreement to be very reasonable given the sensitivity of this yield to the relative energetic thresholds of the two channels. For example, lowering the barrier to isomerization by $1 \mathrm{kcal} / \mathrm{mol}$ doubles the yield of the molecular channel at this energy, which may suggest that our calculated isomerization barrier is slightly too high.

In a detailed study of the shock-wave-induced thermal decomposition of $\mathrm{CF}_{2} \mathrm{Cl}_{2}$ in the temperature range from 1446 to $2667 \mathrm{~K}$, Wagner and co-workers found that the quantum yield for $\mathrm{Cl}$ formation was $2.03 \pm 0.13$, which reflected efficient secondary dissociation of the $\mathrm{CF}_{2} \mathrm{Cl}$ radical (bond energy $=49 \mathrm{kcal} / \mathrm{mol}$ ). $\frac{25}{}$ Although they concluded that $\mathrm{Cl}_{2}$ was not formed, their result is not necessarily at odds with the present work since

Journal of Physical Chemistry Letters, Vol. 1, No. 20 (2010): pg. 3090-3095. DOI. This article is @ American Chemical Society and permission has been granted for this version to appear in e-Publications@Marquette. American Chemical Society does not grant permission for this article to be further copied/distributed or hosted elsewhere without the express permission from American Chemical Society. 
at higher energies, the isomer will decay to both radical and molecular products (Figure $\underline{1}$ ), which lowers the yield of the molecular channel. To illustrate, we extended our RRKM calculations to an energy corresponding to the threshold for secondary dissociation of $\mathrm{CF}_{2} \mathrm{Cl}$ and included a second step to model the decay of the isomer, which would be born with $\sim 60 \mathrm{kcal} / \mathrm{mol}$ of energy. In this calculation, separate scans along the $\mathrm{C}-\mathrm{Cl}$ and $\mathrm{Cl}-\mathrm{Cl}$ coordinates were initially performed at the MP2/6-31G(d) level, and the structures corresponding to the maxima along these paths were then optimized at the MP2/aug-ccpVTZ level, with subsequent single-point energy calculations performed at the $\operatorname{CCSD}(\mathrm{T}) /$ aug-cc-pVTZ level. Details of the input to the rate calculations are provided in Table 3S in the Supporting Information. These calculations predict a reduced yield of molecular products $(<1 \%)$ at this energy, which lies well within the uncertainty of the shock tube measurements.

Thus far, we have shown that an isomerization pathway to molecular products is consistent with experimental observables in the IRMPD of $\mathrm{CF}_{2} \mathrm{Cl}_{2}$. For the closely related $\mathrm{CF}_{2} \mathrm{Br}_{2}$ (Halon-1202) system, Lee and co-workers also examined IRMPD under collisionfree conditions but did not observe $\mathrm{Br}_{2}$ as a product. $\underline{33}$ Figure $\underline{3}$ displays the stationary points on the $\mathrm{CF}_{2} \mathrm{Br} 2 \mathrm{PES}$, calculated at the $\mathrm{CCSD}(\mathrm{T}) / / \mathrm{MP} 2 /$ aug-cc-pVTZ level of theory and corrected for zero-point energy. The $\mathrm{CF}_{2} \mathrm{Br}_{2} \mathrm{PES}$ is qualitatively similar to that shown for $\mathrm{CF}_{2} \mathrm{Cl}_{2}$ in Figure 1; however, one important difference is the relative energetic threshold for the bond fission and isomerization channels. In this case, the isomerization threshold lies $4.3 \mathrm{kcal} / \mathrm{mol}$ higher, which has a dramatic effect on the yield of the molecular channel. Using the approach described above, with details and rate data provided in Tables $4 S$ and $5 S$ and Figure $1 S$ in the Supporting Information, we calculate that at the estimated excess energy ( $7 \mathrm{kcal} / \mathrm{mol}$ ) of the IRMPD experiments of Lee and co-workers, the yield of the molecular channel is $\sim 0.4 \%$, roughly 1 order of magnitude smaller than that predicted for $\mathrm{CF}_{2} \mathrm{Cl}_{2}$. This is consistent with the Lee experiment, where $\mathrm{Br}_{2}$ was not detected. $\underline{33} \mathrm{We}$ emphasize that, while other IRMPD experiments have reported a larger yield of the $\mathrm{CF}_{2}+$ $\mathrm{Br} 2$ channel, this has typically been inferred from measurement of the $\mathrm{CF}_{2}$ product. $\underline{34,35}$

Journal of Physical Chemistry Letters, Vol. 1, No. 20 (2010): pg. 3090-3095. DOI. This article is @ American Chemical Society and permission has been granted for this version to appear in e-Publications@Marquette. American Chemical Society does not grant permission for this article to be further copied/distributed or hosted elsewhere without the express permission from American Chemical Society. 


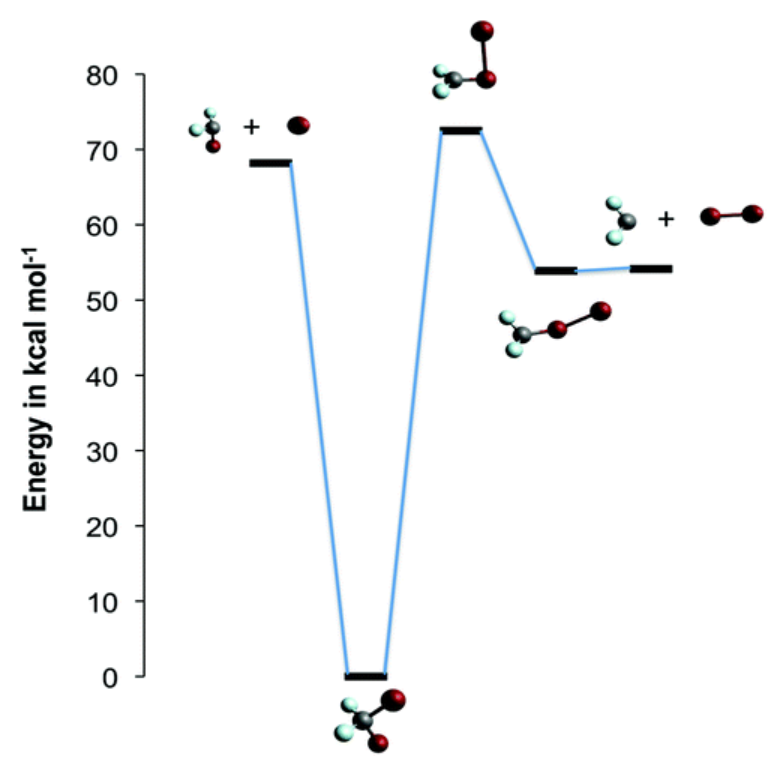

Figure 3. Stationary points (ZPE-corrected) on the $\mathrm{CF}_{2} \mathrm{Br}_{2}$ potential energy surface, calculated at the CCSD(T)//MP2/aug-cc-pVTZ level.

The isomerization channel considered here will be of general importance in the decomposition of polyhalons since the isomerization barrier is typically isoenergetic with simple bond fission. To illustrate, we consider bromoform $\left(\mathrm{CHBr}_{3}\right)$, a model halon that originates primarily from biogenic sources and is a primary producer of bromine in the troposphere and midlatitude lower stratosphere. $\frac{36-41}{1 n}$ contrast to the preceding examples, it is the photochemical decomposition of bromoform that has seen much controversy concerning the branching between radical and molecular products. Excitation in the near-UV accesses $n-\sigma^{*}$ transitions that lead to rapid $\mathrm{C}-\mathrm{Br}$ bond cleavage; $\underline{42}$ however, the formation of $\mathrm{Br}_{2}$ has also been reported, with quantum yields ranging from 0.16 at $266 \mathrm{~nm}$ and 0.26 at $237 \mathrm{~nm} . \underline{43,44}$ This was suggested to involve internal conversion to the ground state and subsequent passage over a three-center TS leading to $\mathrm{CHBr}+\mathrm{Br} 2$ products, calculated to lie $93.1 \mathrm{kcal} / \mathrm{mol}$ above the reactant. $\underline{44}$ However, North and coworkers have examined the photolysis of bromoform at 266 and $193 \mathrm{~nm}$ and conclude that $\mathrm{Br}_{2}$ is not a primary photoproduct, $\underline{45,46}$ which is supported by another recent experiment. $\underline{47}$ We have recently characterized the iso- $\mathrm{CHBr} 3$ species and found a facile photoisomerization pathway similar to that described above for the iso- $\mathrm{CF}_{2} \mathrm{X}_{2}$ species (Reid et al., unpublished results).

Figure $\underline{4}$ displays stationary points on the $\mathrm{CHBr} 3$ PES calculated at the CCSD(T)//MP2/aug-cc-pVTZ level of theory and corrected for zero-point energy. Note that the calculated isomerization barrier lies $\sim 4 \mathrm{kcal} / \mathrm{mol}$ below the radical channel and is more

Journal of Physical Chemistry Letters, Vol. 1, No. 20 (2010): pg. 3090-3095. DOI. This article is @ American Chemical Society and permission has been granted for this version to appear in e-Publications@Marquette. American Chemical Society does not grant permission for this article to be further copied/distributed or hosted elsewhere without the express permission from American Chemical Society. 
than $30 \mathrm{kcal} / \mathrm{mol}$ lower in energy that the three-center transition state calculated by Lin and co-workers. $\underline{44}$ In this case, the isospecies is more strongly bound and lies $\sim 38 \mathrm{kcal} / \mathrm{mol}$ below the threshold for the molecular channel. For completeness, we have shown the asymptotic energy of the $\mathrm{CBr}_{2}+\mathrm{HBr}$ channel; however, we did not locate a saddle point corresponding to this elimination process and conclude that it must occur over a threecenter TS lying at higher energies. Note also that in bromoform, the radical channel lies much lower in energy than the threshold for molecular products, and therefore, at energies near threshold, the isomer can only decay via $\mathrm{Br}-\mathrm{Br}$ bond cleavage, indicated by the dashed line in Figure 4 . Our calculations find no barrier for this process (Reid et al., unpublished results).

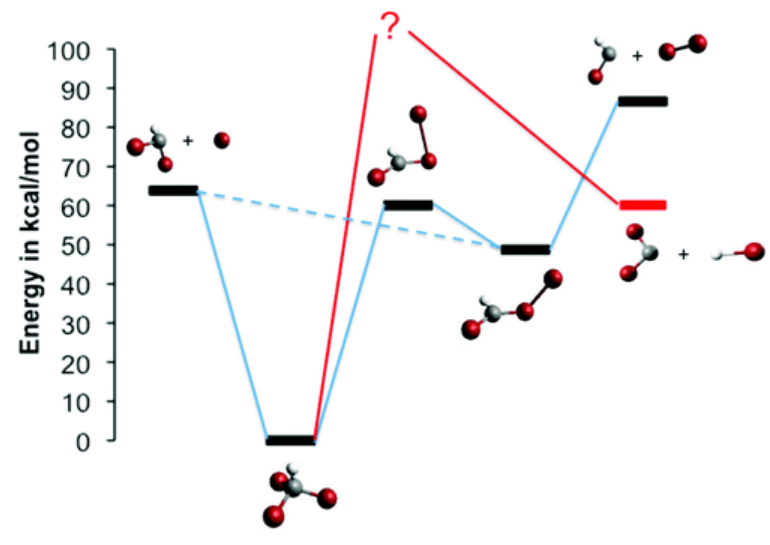

Figure 4. Stationary points (ZPE-corrected) on the $\mathrm{CHBr}_{3}$ potential energy surface, calculated at the CCSD(T)//MP2/aug-cc-pVTZ level.

There is, as of yet, no evidence for the direct importance of isomerization in the photochemical (as opposed to thermal) decomposition of halons; however, an internal conversion pathway leading to the ground-state surface could access the isomer. $\underline{44}$ In order to model the relative yield of radical versus molecular products from such an event, we conducted a two-step rate calculation; details are provided in Tables $6 \mathrm{~s}$ and $7 \mathrm{~s}$ and Figures $2 \mathrm{~s}$ and $3 \mathrm{~s}$ in the Supporting Information. First, at a given total energy of $115 \mathrm{kcal} / \mathrm{mol}$, which corresponds to an excitation wavelength of $248 \mathrm{~nm}$, we calculated the microcanonical rate constants for dissociation and isomerization of the $\mathrm{CHBr} 3$ parent. Second, we treated the subsequent decay of the iso- $\mathrm{CHBr} 3$ statistically, noting that the isomer would be born with an energy of $\sim 66 \mathrm{kcal} / \mathrm{mol}$, and calculated the rate constants for dissociation of the isomer to molecular and radical products using a similar approach to that described above for $\mathrm{CF}_{2} \mathrm{Cl}_{2}$. Consistent with the energetic thresholds shown in Figure $\underline{4}$, our calculations predict $\sim 4 \%$ branching to molecular products. Thus, while isomerization on the ground-state surface will lead to molecular products, the yield is

Journal of Physical Chemistry Letters, Vol. 1, No. 20 (2010): pg. 3090-3095. DOI. This article is @ American Chemical Society and permission has been granted for this version to appear in e-Publications@Marquette. American Chemical Society does not grant permission for this article to be further copied/distributed or hosted elsewhere without the express permission from American Chemical Society. 
relatively small, and, because the quantum yield for internal conversion following UV excitation is by no means unity, this mechanism cannot explain the $16-26 \%$ yield of $\mathrm{Br}_{2}$ reported in some previous photochemical studies. $\underline{43,44}$

Finally, isomerization may also be important in the decomposition of primary radicals derived from halons. To illustrate, Figure $\underline{5}$ displays calculated (CCSDT//MP2/augcc-pVTZ) stationary points on the $\mathrm{CHBr} 2$ PES. To our knowledge, the iso-CHBr2 radical has never before been considered in the literature; however, our calculations show that it is a minimum on the PES which is bound by $\sim 8.6 \mathrm{kcal} / \mathrm{mol}$. As found for the parent halon, bromoform, the barrier to isomerization in the radical is essentially isoenergetic with that for bond fission, calculated to lie lower in energy by $\sim 2 \mathrm{kcal} / \mathrm{mol}$ at this level of theory.

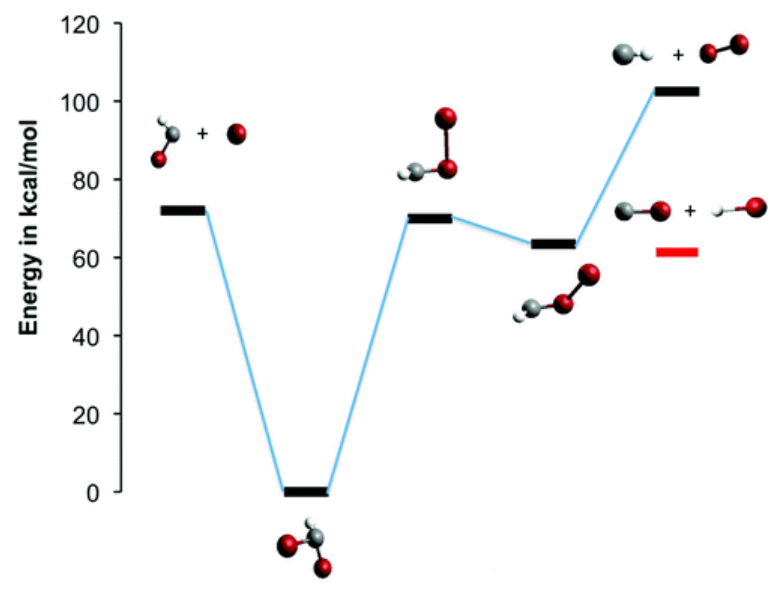

Figure 5. Stationary points (ZPE-corrected) on the $\mathrm{CHBr}_{2}$ potential energy surface, calculated at the CCSD(T)//MP2/aug-cc-pVTZ level.

In summary, we have demonstrated that isomerization is a key pathway to molecular products in the gas-phase decomposition of halons. Our results indicate that the isomerization pathway will be of general importance for both halons and their primary radicals as the barrier is typically isoenergetic with the threshold for simple bond fission. Once formed, the isomer can decay to either radical or molecular products. For bromoform, the radical channel is favored; however, this will not always be the case. For example, in $\mathrm{CFBr}$, the molecular and radical channels are nearly isoenergetic due to the greater stability of the carbene cofragment. In condensed phases, isomerization will be more important as preferential solvation of the ion-pair-dominated transition-state structure for isomerization will result in a significant lowering of the barrier.

Journal of Physical Chemistry Letters, Vol. 1, No. 20 (2010): pg. 3090-3095. DOI. This article is @ American Chemical Society and permission has been granted for this version to appear in e-Publications@Marquette. American Chemical Society does not grant permission for this article to be further copied/distributed or hosted elsewhere without the express permission from American Chemical Society. 


\section{Computational Methods}

All calculations were performed using the Gaussian 09 or GAMESS suites of electronic structure programs on the Teragrid or MU Pere cluster. 48,49 Unconstrained geometry optimizations and frequency calculations were performed using post-Hartree-Fock (MP2) methods in combination with Dunning's correlation consistent aug-cc-pVTZ basis set. All MP2 frequencies were scaled by a factor of 0.96 . $\underline{\text { 2 }}$ The stability of the MP2 wave function at the transition state was tested, and the single reference wavefunction was found in all cases to be stable. Single-point energy calculations on the MP2-optimized structures were carried out at the CCSD(T)/aug-cc-pVTZ level.

\section{Acknowledgment}

The authors thank Prof. Rajendra Rathore for helpful comments. Support of the National Science Foundation (Grant CHE-0717960), the Donors of the Petroleum Research Fund of the American Chemical Society (Grant 48740-ND6), the NSF Teragrid project (Grant TG-CHE100075), and the NSF funded Pere cluster at Marquette is acknowledged.

\section{References}

1Solomon, S.; Portmann, R. W.; Thompson, D. W. J. Contrasts Between Antarctic and Arctic Ozone Depletion Proc. Natl. Acad. Sci. U.S.A. 2007, 104, 445- 449

${ }^{2}$ Cameron, M. R.; Bacskay, G. B. Stabilities, Excitation Energies, and Dissociation Reactions of $\mathrm{CF}_{2} \mathrm{Cl}_{2}$ and $\mathrm{CF}_{2} \mathrm{Br}_{2}$ : Quantum Chemical Computations of Heats of Formation of Fluorinated Methanes, Methyls, and Carbenes J. Phys. Chem. A 2000, 104, 11212- 11219

3ZZheng, X.; Fang, W. H.; Phillips, D. L. Transient Resonance Raman Spectroscopy and Density Functional Theory Investigation of Iso-polyhalomethanes Containing Bromine and/or Iodine Atoms J. Chem. Phys. 2000, 113, 10934

4Li, Y. L.; Zhao, C.; Kwok, W. M.; Guan, X.; Zuo, P.; Phillips, D. L. Observation of a HI Leaving Group Following Ultraviolet Photolysis of $\mathrm{CH}_{2} \mathrm{I}_{2}$ in Water and an $\mathrm{Ab}$ Initio Investigation of the $\mathrm{O}-\mathrm{H}$ Insertion/HI Elimination Reactions of the $\mathrm{CH}_{2} \mathrm{I}-\mathrm{I}$ Isopolyhalomethane Species with $\mathrm{H}_{2} \mathrm{O}$ and $2 \mathrm{H}_{2} \mathrm{O}$ J. Chem. Phys. 2003, 119, 4671- 4681

5Kwok, W. M.; Zhao, C.; Li, Y.-L.; Guan, X.; Phillips, D. L. Direct Observation of an Isopolyhalomethane O-H Insertion Reaction with Water: Picosecond Time-Resolved Resonance Raman (ps-TR3) Study of the Isobromoform Reaction with Water to Produce a $\mathrm{CHBr}_{2} \mathrm{OH}$ product J. Chem. Phys. 2004, 120, 3323- 3332

6Kwok, W. M.; Zhao, C.; Li, Y.-L.; Guan, X.; Wang, D.; Phillips, D. L. Water-Catalyzed Dehalogenation Reactions of Isobromoform and Its Reaction Products J. Am. Chem. Soc. 2004, 126, 3119- 3131

ZPhillips, D. L.; Fang, W. H.; Zheng, X.; Li, Y. L.; Wang, D.; Kwok, W. M. Isopolyhalomethanes: Their Formation, Structures, Properties and Cyclopropanation Reactions with Olefins Curr. Org. Chem. $2004,8,739-755$

Journal of Physical Chemistry Letters, Vol. 1, No. 20 (2010): pg. 3090-3095. DOI. This article is @ American Chemical Society and permission has been granted for this version to appear in e-Publications@Marquette. American Chemical Society does not grant permission for this article to be further copied/distributed or hosted elsewhere without the express permission from American Chemical Society. 
NOT THE PUBLISHED VERSION; this is the author's final, peer-reviewed manuscript. The published version may be accessed by following the link in the citation at the bottom of the page.

${ }^{8}$ Guan, X. G.; Lin, X. F.; Kwok, W. M.; Du, Y.; Li, Y. L.; Zhao, C. Y.; Wang, D. Q.; Phillips, D. L. Ultraviolet Photolysis of $\mathrm{CH}_{2} \mathrm{I}_{2}$ in Methanol: $\mathrm{O}-\mathrm{H}$ Insertion and HI Elimination Reactions to Form a Dimethoxymethane Product J. Phys. Chem. A 2005, 109, 1247- 1256

9Li, Y. L.; Zhao, C.; Guan, X.; Phillips, D. L. Ab Initio Investigation of the O-H Insertion Reactions of $\mathrm{CH}_{2} \mathrm{X}-\mathrm{X}(\mathrm{X}=\mathrm{Cl}, \mathrm{Br}, \mathrm{I})$ Isopolyhalomethanes with Water Res. Chem. Intermed. 2005, 31, 557565

10Lin, X. F.; Guan, X. G.; Kwok, W. M.; Zhao, C. Y.; Du, Y.; Li, Y. L.; Phillips, D. L. Water-Catalyzed O-H Insertion/HI Elimination Reactions of Isodihalomethanes $\left(\mathrm{CH}_{2} \mathrm{X}-\mathrm{I}\right.$, where $\left.\mathrm{X}=\mathrm{Cl}, \mathrm{Br}, \mathrm{I}\right)$ with Water and the Dehalogenation of Dihalomethanes in Water-Solvated Environments J. Phys. Chem. A 2005, 109, 981- 998

11Lin, X. F.; Zhao, C. Y.; Phillips, D. L. An Ab Initio Study of the Reactions of $\mathrm{CH}_{2} \mathrm{X}-\mathrm{X}(\mathrm{X}=\mathrm{Cl}, \mathrm{Br}, \mathrm{I})$ Isopolyhalomethanes with $\mathrm{nCH}_{3} \mathrm{OH} \mathrm{Mol.} \mathrm{Simul.} \mathrm{2005,} \mathrm{31,} \mathrm{483-} 488$

12El-Khoury, P. Z.; Kwok, W. M.; Guan, X. G.; Ma, C. S.; Phillips, D. L.; Tarnovsky, A. N. Photochemistry of Iodoform in Methanol: Formation and Fate of the Iso- $\mathrm{CHI}_{2}-\mathrm{I}$ Photoproduct ChemPhysChem 2009, 10, 1895- 1900

13Maier, G.; Reisenauer, H. P. Photoisomerization of Dihalomethanes Angew. Chem., Int. Ed. Engl. 1986, 25, 819- 822

14Maier, G.; Reisenauer, H. P.; Hu, J.; Schaad, L. J.; Hess, B. A. Photochemical Isomerization of Dihalomethanes in Argon Matrixes J. Am. Chem. Soc. 1990, 112, 5117- 5122

15Maier, G.; Reisenauer, H. P.; Hu, J.; Hess, B. A.; Schaad, L. J. Photoisomerization of Tetrachloromethane in an Argon Matrix Tetrahedron Lett. 1989, 30, 4105- 4108

16Petro, B. J.; Tweeten, E. D.; Quandt, R. W. Dispersed Fluorescence and Computational Study of the $2 \times$ $193 \mathrm{~nm}$ Photodissociation of $\mathrm{CHBr}_{3}$ and $\mathrm{CBr}_{4}$ J. Phys. Chem. A 2004, 108, 384- 391

17Tweeten, E. D.; Petro, B. J.; Quandt, R. W. Formation of Molecular Iodine from the Two-Photon Dissociation of $\mathrm{CI}_{4}$ and $\mathrm{CHI}_{3}$ : An Experimental and Computational Study J. Phys. Chem. A 2003, $107,19-24$

18El-Khoury, P. Z.; George, L.; Kalume, A.; Ault, B. S.; Tarnovsky, A. N.; Reid, S. A. Frequency and Ultrafast Time Resolved Study of Iso-- $\mathrm{CF}_{2} \mathrm{I}_{2}$ J. Chem. Phys. 2009, 132, 124501

${ }^{19}$ George, L.; Kalume, A.; El-Khoury, P. Z.; Tarnovsky, A.; Reid, S. A. Matrix Isolation and Computational Study of Isodifluorodibromomethane $\left(\mathrm{F}_{2} \mathrm{CBr}-\mathrm{Br}\right)$ : A Route to $\mathrm{Br}_{2}$ Formation in $\mathrm{CF}_{2} \mathrm{Br}_{2}$ Photolysis J. Chem. Phys. 2010, 132, 084503

20Morrison, R. J. S.; Loring, R. F.; Farley, R. L.; Grant, E. R. Energetics of Molecular Elimination in the Infrared Multi-Photon Dissociation of $\mathrm{CF}_{2} \mathrm{Cl}_{2}, \mathrm{CF}_{2} \mathrm{Br}_{2}, \mathrm{CF}_{2} \mathrm{ClBr}$, and $\mathrm{CFCl}_{3}$ J. Chem. Phys. 1981, 75, $148-158$

21Krajnovich, D.; Huisken, F.; Zhang, Z.; Shen, Y. R.; Lee, Y. T. Competition Between Atomic and Molecular Chlorine Elimination in the Infrared Multiphoton Dissociation of $\mathrm{CF}_{2} \mathrm{CI}_{2}$ J. Chem. Phys. 1982, 77, 5977- 5989

222Rayner, D. M.; Kimel, S.; Hackett, P. A. On the Source of Difluorocarbene in IRMPD (Infrared Multiphoton Dissociation) of Dichlorodifluoromethane Chem. Phys. Lett. 1983, 96, 678- 680

23 Wollbrandt, J.; Strube, W.; Rossberg, M.; Linke, E. Determination of the Density of IRMPD-Generated Radicals by Transmission and LIF Measurements Spectrochim. Acta, Part A 1990, 46A, 475- 477

242Zitter, R. N.; Lau, R. A.; Wills, K. S. Infrared Laser Induced Reaction of Dichlorodifluoromethane J. Am. Chem. Soc. $1975,97,2578-2579$

Journal of Physical Chemistry Letters, Vol. 1, No. 20 (2010): pg. 3090-3095. DOI. This article is @ American Chemical Society and permission has been granted for this version to appear in e-Publications@Marquette. American Chemical Society does not grant permission for this article to be further copied/distributed or hosted elsewhere without the express permission from American Chemical Society. 
25 Kumaran, S. S.; Lim, K. P.; Michael, J. V.; Wagner, A. F. Thermal Decomposition of $\mathrm{CF}_{2} \mathrm{Cl}_{2}$ J. Phys. Chem. $1995,99,8673-8680$

26Note that the transition state for isomerization can be considered as an asymmetric three-centered transition state.

27Lewerenz, M.; Nestmann, B.; Bruna, P. J.; Peyerimhoff, S. D. The Electronic-Spectrum, Photodecomposition and Dissociative Electron-Attachment of $\mathrm{CF}_{2} \mathrm{Cl}_{2}-\mathrm{An} \mathrm{Ab}$ initio Configuration-Interaction Study J. Mol. Chem.: THEOCHEM 1985, 24, 329- 342

28 Mokrushin, V.; Bedanov, V.; Tsang, W.; Zachariah, M.; Knyasev, V. CHEMRATE: A Calculational Database for Unimolecular Reactions, 1.5.8; National Institute of Standards and Technology: Gaithersburg, MD, 2009.

29 Khundkar, L. R.; Marcus, R. A.; Zewail, A. H. Unimolecular Reactions at Low Energies and Rrkm Behavior - Isomerization and Dissociation J. Phys. Chem. 1983, 87, 2473- 2476

30Smith, G. P.; Manion, J. A.; Rossi, M. J.; Rodgers, A. S.; Golden, D. M. Relationship Between Bond Dissociation Energies and Activation Energies for Bond Scission Reactions Int. J. Chem. Kinet. 1994, 26, 211

31Smith, G. P.; Golden, D. M. Application of RRKM Theory to the Reactions $\mathrm{OH}+\mathrm{NO}_{2}+\mathrm{N}_{2} \rightarrow \mathrm{HONO} 2+\mathrm{N}_{2}$ (1) and $\mathrm{ClO}+\mathrm{NO}_{2}+\mathrm{N}_{2} \rightarrow \mathrm{ClONO}_{2}+\mathrm{N}_{2}$ (2); A Modified Gorin Model Transition State Int. J. Chem. Kinetics 1978, 10

32Sinha, P.; Boesch, S. E.; Gu, C. M.; Wheeler, R. A.; Wilson, A. K. Harmonic Vibrational Frequencies: Scaling Factors for HF, B3LYP, and MP2 Methods in Combination with Correlation Consistent Basis Sets J. Phys. Chem. A 2004, 108, 9213- 9217

333udbo, A. S.; Schulz, P. A.; Grant, E. R.; Shen, Y. R.; Lee, Y. T. Simple Bond Rupture Reactions in Multiphoton Dissociation of Molecules J. Chem. Phys. 1979, 70, 912- 929

34Stephenson, J. C.; King, D. S. Energy Partitioning in the Collision-Free Multiphoton Dissociation of Molecules: Energy of $\mathrm{XCF}_{2}$ from $\mathrm{CF}_{2} \mathrm{HCI}, \mathrm{CF}_{2} \mathrm{Br}_{2}$ and $\mathrm{CF}_{2} \mathrm{CI}_{2}$ J. Chem. Phys. 1978, 69, 1485- 1492

35 Abel, B.; Hippler, H.; Lange, N.; Schuppe, J.; Troe, J. Competition between Unimolecular C-Br-Bond Fission and $\mathrm{Br}_{2}$ Elimination in Vibrationally Highly Excited $\mathrm{CF}_{2} \mathrm{Br}_{2}$ J. Chem. Phys. 1994, 101, 9681- 9690

36Cota, G. F.; Sturges, W. T. Biogenic Bromine Production in the Arctic Mar. Chem. 1997, 56, 181- 192

37Class, T.; Kohnle, R.; Ballschmiter, K. Chemistry of Organic Traces in Air 0.7. Bromochloromethanes and Bromochloromethanes in Air over the Atlantic-Ocean Chemosphere 1986, 15, 429- 436

38Sturges, W. T.; Oram, D. E.; Carpenter, L. J.; Penkett, S. A.; Engel, A. Bromoform as a Source of Stratospheric Bromine Geophys. Res. Lett. 2000, 27, 2081- 2084

39 Barrie, L. A.; Bottenheim, J. W.; Schnell, R. C.; Crutzen, P. J.; Rasmussen, R. A. Ozone Destruction and Photochemical-Reactions at Polar Sunrise in the Lower Arctic Atmosphere Nature 1988, 334, 138- 141

40Schauffler, S. M.; Atlas, E. L.; Flocke, F.; Lueb, R. A.; Stroud, V.; Travnicek, W. Measurements of Bromine Containing Organic Compounds at the Tropical Tropopause Geophys. Res. Lett. 1998, 25, 317320

41Dvortsov, V. L.; Geller, M. A.; Solomon, S.; Schauffler, S. M.; Atlas, E. L.; Blake, D. R. Rethinking Reactive Halogen Budgets in the Midlatitude Lower Stratosphere Geophys. Res. Lett. 1999, 26, 16991702

Journal of Physical Chemistry Letters, Vol. 1, No. 20 (2010): pg. 3090-3095. DOI. This article is @ American Chemical Society and permission has been granted for this version to appear in e-Publications@Marquette. American Chemical Society does not grant permission for this article to be further copied/distributed or hosted elsewhere without the express permission from American Chemical Society. 
42Peterson, K. A.; Francisco, J. S. Should Bromoform Absorb at Wavelengths Longer than $300 \mathrm{~nm}$ J. Chem. Phys. 2002, 117, 6103-6107

43XXu, D. D.; Francisco, J. S.; Huang, J.; Jackson, W. M. Ultraviolet Photodissociation of Bromoform at 234 and $267 \mathrm{~nm}$ by Means of Ion Velocity Imaging J. Chem. Phys. 2002, 117, 2578- 2585

44Huang, H. Y.; Chuang, W. T.; Sharma, R. C.; Hsu, C. Y.; Lin, K. C.; Hu, C. H. Molecular Elimination of $\mathrm{Br}_{2}$ in $248 \mathrm{~nm}$ Photolysis of Bromoform Probed by Using Cavity Ring-down Absorption Spectroscopy J. Chem. Phys. 2004, 121, 5253- 5260

45McGivern, W. S.; Sorkhabi, O.; Suits, A. G.; Derecskei-Kovacs, A.; North, S. W. Primary and Secondary Processes in the Photodissociation of $\mathrm{CHBr}_{3}$ J. Phys. Chem. A 2000, 104, 10085- 10091

46Zou, P.; Shu, J. N.; Sears, T. J.; Hall, G. E.; North, S. W. Photodissociation of Bromoform at $248 \mathrm{~nm}$ : Single and Multiphoton Processes J. Phys. Chem. A 2004, 108, 1482- 1488

47Yang, S. X.; Hou, G. Y.; Dai, J. H.; Chang, C. H.; Chang, B. C. Spectroscopic Investigation of the Multiphoton Photolysis Reactions of Bromomethanes $\left(\mathrm{CHBr}_{3}, \mathrm{CHBr}_{2} \mathrm{Cl}, \mathrm{CHBrCl}_{2}\right.$, and $\left.\mathrm{CH}_{2} \mathrm{Br}_{2}\right)$ at NearUltraviolet Wavelengths J. Phys. Chem. A2010, 114, 4785- 4790

48Frisch, M. J.; et al. GAUSSIAN 09, revision A1; Gaussian, Inc.: Wallingford, CT, 2009.

49GGordon, M. S.; Schmidt, M. W., Advances in Electronic Structure Theory: GAMESS a Decade Later. In Theory and Applications of Computational Chemistry: The First Forty Years; Dykstra, C. E.; Frenking, G.; Kim, K. S.; Scuseria, G. E., Eds.; Elsevier: Amsterdam, The Netherlands, 2005; pp $1167-1189$.

\section{Supporting Information}

Seven tables and three figures detailing the input into and results from microcanonical rate constant calculations for $\mathrm{CF}_{2} \mathrm{Cl}_{2}, \mathrm{CF}_{2} \mathrm{Br}_{2}$, and $\mathrm{CHBr}_{3}$. This material is available free of charge via the Internet at http://pubs.acs.org.

Journal of Physical Chemistry Letters, Vol. 1, No. 20 (2010): pg. 3090-3095. DOI. This article is @ American Chemical Society and permission has been granted for this version to appear in e-Publications@Marquette. American Chemical Society does not grant permission for this article to be further copied/distributed or hosted elsewhere without the express permission from American Chemical Society. 


\section{Supporting information:}

Isomerization is a Key Path to Molecular Products in the Gas-phase Decomposition of Halons Aimable Kalume, Lisa George, and Scott A. Reid*

Department of Chemistry, Marquette University, Milwaukee, WI 53201-1881 USA

Table 1S. Optimized (MP2/aug-cc-pVTZ) geometrical parameters of species associated with stationary points on the $\mathrm{CF}_{2} \mathrm{Cl}_{2}$ PES. All bond lengths are in $\AA$, bond angles in degrees.

\begin{tabular}{|c|c|c|c|c|c|c|c|}
\hline \multicolumn{7}{|c|}{ This work } \\
\hline \multicolumn{2}{|c|}{$\mathbf{C F}_{\mathbf{2}} \mathbf{C l}_{\mathbf{2}}$} & \multicolumn{2}{c|}{ iso- $\mathbf{C F}_{\mathbf{2}} \mathbf{C l}_{\mathbf{2}}$} & \multicolumn{2}{c|}{$\mathbf{C F}_{\mathbf{2}} \mathbf{C l}_{\mathbf{2}} \mathbf{T S ~ 1}$} & \multicolumn{2}{c|}{ iso-CF $_{\mathbf{2}} \mathbf{C l}_{\mathbf{2}} \mathbf{T S}^{\mathbf{2}}$} \\
\hline Parameter & Value & Parameter & Value & Parameter & Value & Parameter & Value \\
\hline$C-F$ & 1.3341 & $C-F$ & 1.3094 & $C-F$ & 1.2867 & $C-F$ & 1.2776 \\
\hline$C-C l$ & 1.7561 & $C-C l$ & 1.6354 & $C-C l_{1}$ & 1.6672 & $C-C l$ & 1.5722 \\
\hline$F-C-C l$ & 109.36 & $C l-C l$ & 2.3576 & $C-C l_{2}$ & $3.0000 \mathrm{a}$ & $C l-C l$ & 2.6516 \\
\hline$F-C-F$ & 107.76 & $F-C-F$ & 110.63 & $F-C-C l_{1}$ & 118.10 & $F-C-F$ & 114.07 \\
\hline & & $F-C-C l$ & 119.95 & $C l_{1}-C-C l_{2}$ & 101.43 & $F-C-C l$ & 122.92 \\
\hline & & $C-C l-C l$ & 131.98 & $C l_{2}-C-C l_{1}-F$ & 108.51 & $C-C l-C l$ & 85.9 \\
\hline & & $F-C-C l-C l$ & 71.69 & & & $F-C-C l-C l$ & 88.4 \\
\hline
\end{tabular}

a Constrained to this value. 
Table 2S. Calculated (CCSD(T)//MP2/aug-cc-pVTZ) parameters of species associated with stationary points on the $\mathrm{CF}_{2} \mathrm{Cl}_{2}$ PES used for input to microcanonical rate calculations. All vibrational frequencies (given in $\mathrm{cm}^{-1}$ ) have been scaled by 0.96 . Moments of inertia are given in amu $\AA^{2}$, energies in $\mathrm{cm}^{-1}$.

\begin{tabular}{|c|c|c|c|}
\hline $\mathrm{CF}_{2} \mathrm{Cl}_{2}$ & $\mathrm{CF}_{2} \mathrm{Cl}_{2}$ TS Model 1 & $\mathrm{CF}_{2} \mathrm{Cl}_{2}$ TS Model $2^{a}$ & isomerization TS \\
\hline Energy: 0 & Energy: $28,211^{b}$ & Energy: 28.211 & Energy: 28,625 \\
\hline $\begin{array}{c}\text { Frequencies: } 252.2 \\
311.8,424.4,426.4 \\
445.9,648.2,888.9 \\
1070.9,1124.7\end{array}$ & $\begin{array}{c}\text { Frequencies: }-130,43.0 \\
52.7,358.2,410.3,585.1 \\
794.6,1052.2,1071.9\end{array}$ & $\begin{array}{c}\text { Frequencies: } 355.5 \\
414.2,584.3,761.4 \\
1131.0,1184.0\end{array}$ & $\begin{array}{c}\text { Frequencies: -362, } \\
\text { 99.7, 193.7, 353.2, 413.1, } \\
\text { 504.1, 793.4, 1389.0, } \\
1401.0\end{array}$ \\
\hline $\begin{array}{c}\text { Active Rotation }(\boldsymbol{K}) \text { : } \\
\qquad I_{a}=123.44\end{array}$ & $\begin{array}{c}\text { Active Rotation }(\boldsymbol{K}) \text { : } \\
\qquad I_{a}=133.0\end{array}$ & $\begin{array}{c}\text { Ext. Active Rotation } \\
\qquad \begin{array}{c}\text { (K): } \\
I_{a}=46.2\end{array}\end{array}$ & $\begin{array}{c}\text { Active Rotation }(\boldsymbol{K}): \\
I_{a}=119.93\end{array}$ \\
\hline $\begin{array}{c}\text { Adiabatic Rotation } \\
\text { (J): } \\
I_{b}=I_{c}=210.52\end{array}$ & $\begin{array}{c}\text { Adiabatic Rotation (): } \\
I_{b}=I_{c}=582.2\end{array}$ & $\begin{array}{l}\text { Adiabatic Rotation (): } \\
\qquad I_{b}=I_{c}=578.89\end{array}$ & $\begin{array}{c}\text { Adiabatic Rotation (): } \\
\qquad I_{b}=I_{c}=279.69\end{array}$ \\
\hline & & $\begin{array}{l}\text { Int. Active Rotation (2- } \\
\text { D): } \\
I=118.9\end{array}$ & \\
\hline & & $\begin{array}{c}\text { Benson } a \text { parameter: } \\
0.02\end{array}$ & \\
\hline
\end{tabular}

${ }^{a}$ Gorin model. The transition state moments of inertia were obtained from the centrifugal maximum following the procedure outlined in ref. 32 . 
Table 3S. Calculated (CCSD(T)//MP2/aug-cc-pVTZ) parameters of species associated with stationary points on the iso- $\mathrm{CF}_{2} \mathrm{Cl}_{2}$ PES used for input to microcanonical rate calculations. All vibrational frequencies (given in $\mathrm{cm}^{-1}$ ) have been scaled by 0.96 . Moments of inertia are given in amu $\bullet \AA^{2}$, energies in $\mathrm{cm}^{-1}$.

\begin{tabular}{|c|c|c|}
\hline Iso- $\mathrm{CF}_{2} \mathrm{Cl}_{2}$ & $\begin{array}{l}\text { Iso- } \mathrm{CF}_{2} \mathrm{Cl}_{2} \mathrm{TS} \\
\text { (radical) }\end{array}$ & Iso- $\mathrm{CF}_{2} \mathrm{Cl}_{2} \mathrm{TS}$ (molecular) \\
\hline Energy: $0^{a}$ & Energy: 3760 & Energy: 2387 \\
\hline $\begin{array}{c}\text { Frequencies: } 92.8,128.5, \\
323.9,393.6,473.5,505.6, \\
713.4,1234.0,1263.0\end{array}$ & $\begin{array}{c}\text { Frequencies: }-160.7,17.6,21.1 \\
362.98,414.4,574.6,942.6 \\
1008.4,1109.7\end{array}$ & $\begin{array}{c}\text { Frequencies: }-144.0,115.6 \\
\text { 144.8, 385.3, 410.4, 462.7, } \\
701.3,1222.0,1336.0\end{array}$ \\
\hline $\begin{array}{c}\text { Active Rotation }(\boldsymbol{K}): \\
\quad I_{a}=74.1\end{array}$ & $\begin{array}{c}\text { Active Rotation }(\boldsymbol{K}) \text { : } \\
\qquad I_{a}=119.8\end{array}$ & $\begin{array}{c}\text { Active Rotation }(\boldsymbol{K}) \text { : } \\
\qquad I_{a}=138.9\end{array}$ \\
\hline $\begin{array}{c}\text { Adiabatic Rotation (): } \\
I_{b}=I_{c}=371.4\end{array}$ & $\begin{array}{c}\text { Adiabatic Rotation (): } \\
I_{b}=I_{c}=470.1\end{array}$ & $\begin{array}{c}\text { Adiabatic Rotation }(\boldsymbol{)}) \\
I_{b}=I_{c}=340.5\end{array}$ \\
\hline
\end{tabular}

${ }^{a}$ Energies relative to iso- $\mathrm{CF}_{2} \mathrm{Cl}_{2}$ minimum. 
Table 4S. Optimized (MP2/aug-cc-pVTZ) geometrical parameters of species associated with stationary points on the $\mathrm{CF}_{2} \mathrm{Br}_{2}$ PES. All bond lengths are in $\AA$, bond angles in degrees.

\begin{tabular}{|c|c|c|c|c|c|}
\hline \multicolumn{6}{|c|}{ This work } \\
\hline \multicolumn{2}{|c|}{$\mathrm{CF}_{2} \mathrm{Br}_{2}$} & \multicolumn{2}{|c|}{ iso- $-\mathrm{CF}_{2} \mathrm{Br}_{2}$} & \multicolumn{2}{|c|}{ iso- $-\mathrm{CF}_{2} \mathrm{Br}_{2} \mathrm{TS}$} \\
\hline Parameter & Value & Parameter & Value & Parameter & Value \\
\hline$C-F$ & 1.3349 & $C-F$ & 1.3102 & $C-F$ & 1.2828 \\
\hline$C-B r$ & 1.9271 & $C-B r$ & 1.8241 & $C-B r$ & 1.7293 \\
\hline$F-C-B r$ & 112.00 & $B r-B r$ & 2.5805 & $B r-B r$ & 2.9150 \\
\hline \multirow[t]{4}{*}{$F-C-F$} & 107.72 & $F-C-F$ & 109.50 & $F-C-F$ & 113.68 \\
\hline & & $F-C-B r$ & 119.70 & $F-C-B r$ & 123.16 \\
\hline & & $C-B r-B r$ & 140.00 & $\mathrm{C}-\mathrm{Br}-\mathrm{Br}$ & 80.70 \\
\hline & & $F-C-B r-B r$ & 70.07 & $F-C-B r-B r$ & 90.19 \\
\hline \multirow{2}{*}{\multicolumn{6}{|c|}{ Previous Work }} \\
\hline & & & & & \\
\hline & & \multicolumn{2}{|c|}{ iso- $\mathrm{CF}_{2} \mathrm{Br}_{2}{ }^{a}$} & & \\
\hline & & Parameter & Value & & \\
\hline & & $C-F$ & 1.296 & & \\
\hline & & $C-B r$ & 2.026 & & \\
\hline & & $B r-B r$ & 2.528 & & \\
\hline & & $F-C-F$ & 108.6 & & \\
\hline & & $F-C-B r$ & 119.6 & & \\
\hline & & $C-B r-B r$ & 157.1 & & \\
\hline
\end{tabular}

a Calculated at B3LYP/aug-cc-pVTZ level (ref. 19). 
Table 5S. Calculated (CCSD(T)//MP2/aug-cc-pVTZ) parameters of species associated with stationary points on the $\mathrm{CF}_{2} \mathrm{Br}_{2}$ PES used for input to microcanonical rate calculations. All vibrational frequencies (given in $\mathrm{cm}^{-1}$ ) have been scaled by 0.96 . Moments of inertia are given in amu $\bullet \AA^{2}$, energies in $\mathrm{cm}^{-1}$.

\begin{tabular}{|c|c|c|}
\hline $\mathrm{CF}_{2} \mathrm{Br}_{2}$ & $\mathrm{CF}_{2} \mathrm{Br}_{2} \mathrm{TS}^{b}$ & isomerization TS \\
\hline Energy: $0^{a}$ & Energy: 24,291 & Energy: 25,564 \\
\hline $\begin{array}{c}\text { Frequencies: } 162.8,271.7 \\
325.6,335.9,358.5,602.8 \\
812.1,1057.8,1109.1\end{array}$ & \multirow{5}{*}{$\begin{array}{c}\text { Frequencies: } 303.3,327.2,566.8 \text {, } \\
681.4,1123.0,1175.0 \\
\text { Ext. Active Rotation (K): } \\
I_{a}=46.1 \\
\text { Adiabatic Rotation }(\boldsymbol{)}): \\
I_{b}=I_{c}=1073.0 \\
\text { Int. Active Rotation (2-D): } \\
I=191.4 \\
\text { Benson } \boldsymbol{a} \text { parameter: } 0.02\end{array}$} & $\begin{array}{c}\text { Frequencies: }-366,92.5,137.6 \\
243.6,350.5,430.8,707.8 \\
1302.0,1358.0\end{array}$ \\
\hline $\begin{array}{c}\text { Active Rotation }(\boldsymbol{K}) \text { : } \\
I_{a}=156.8\end{array}$ & & $\begin{array}{c}\text { Active Rotation }(\boldsymbol{K}) \text { : } \\
I_{a}=101.9\end{array}$ \\
\hline $\begin{array}{c}\text { Adiabatic Rotation (): } \\
\qquad I_{b}=I_{c}=485.1\end{array}$ & & $\begin{array}{c}\text { Adiabatic Rotation (⿹): } \\
\qquad I_{b}=I_{c}=489.7\end{array}$ \\
\hline & & \\
\hline & & \\
\hline
\end{tabular}

a Relative to $\mathrm{CF}_{2} \mathrm{Br}_{2}$ minimum. ${ }^{b}$ Gorin transition state. The moments of inertia were calculated from the centrifugal maximum using the procedure outlined in ref. 32. 
Table 6S. Optimized (MP2/aug-cc-pVTZ) geometrical parameters of species associated with stationary points on the $\mathrm{CHBr}_{3}$ PES. All bond lengths are in $\AA$, bond angles in degrees.

\begin{tabular}{|c|c|c|c|c|c|c|c|}
\hline \multicolumn{8}{|c|}{ This work } \\
\hline \multicolumn{2}{|c|}{$\mathrm{CHBr}_{3}$} & \multicolumn{2}{|c|}{ iso- $\mathrm{CHBr}_{3}$} & \multicolumn{2}{|c|}{ Isomerization TS } & \multicolumn{2}{|c|}{$\begin{array}{l}\text { iso- } \mathrm{CHBr}_{3} \mathrm{TS} \\
\text { to } \mathrm{CHBr}+\mathrm{Br}_{2}\end{array}$} \\
\hline Parameter & Value & Parameter & Value & Parameter & Value & Parameter & Value \\
\hline$C-H$ & 1.0811 & $C-H$ & 1.0814 & $C-H$ & 1.0797 & $C-H$ & 1.1066 \\
\hline$C-B r$ & 1.9157 & $C-B r_{1}$ & 1.8456 & $C-B r_{1}$ & 1.8184 & $C-B r_{1}$ & 1.8456 \\
\hline $\mathrm{H}-\mathrm{C}-\mathrm{Br}$ & 107.24 & $\mathrm{C}-\mathrm{Br}_{2}$ & 1.7744 & $\mathrm{C}-\mathrm{Br}_{2}$ & 1.7422 & $\mathrm{C}-\mathrm{Br}_{2}$ & $3.0000^{\mathrm{a}}$ \\
\hline \multirow[t]{4}{*}{$B r-C-B r$} & 111.49 & $B r_{2}-B r_{3}$ & 2.6111 & $B r_{2}-B r_{3}$ & 2.8723 & $B r_{2}-B r_{3}$ & 2.3353 \\
\hline & & $H-C-B r_{1}$ & 116.58 & $H-C-B r_{1}$ & 118.10 & $H-C-B r_{1}$ & 103.53 \\
\hline & & $\mathrm{C}-\mathrm{Br}_{2}-\mathrm{Br}_{3}$ & 118.60 & $\mathrm{C}-\mathrm{Br}_{2}-\mathrm{Br}_{3}$ & 76.61 & $C-B r_{2}-B r_{3}$ & 174.18 \\
\hline & & $\mathrm{H}-\mathrm{C}-\mathrm{Br}_{2}-\mathrm{Br}_{3}$ & 78.96 & $\mathrm{H}-\mathrm{C}-\mathrm{Br}_{2}-\mathrm{Br}_{3}$ & 83.06 & $\mathrm{H}-\mathrm{C}-\mathrm{Br}_{2}-\mathrm{Br}_{3}$ & 180.00 \\
\hline & & & & & & & \\
\hline & & & & & & & \\
\hline \multicolumn{8}{|c|}{ Previous Work $^{b}$} \\
\hline \multicolumn{2}{|c|}{$\mathrm{CHBr}_{3}$} & \multicolumn{2}{|c|}{ iso-CHBr $_{3}$} & \multicolumn{2}{|c|}{ Isomerization TS } & \multicolumn{2}{|c|}{ Molecular TS } \\
\hline $\mathrm{C}-\mathrm{H}$ & 1.094 & $C-H$ & 1.0814 & $C-H$ & 1.089 & $\mathrm{C}-\mathrm{H}$ & 1.126 \\
\hline$C-B r$ & 2.022 & $C-B r_{1}$ & 1.8456 & $C-B r_{1}$ & 1.924 & $C-B r_{1}$ & 2.040 \\
\hline $\mathrm{H}-\mathrm{C}-\mathrm{Br}$ & 107.00 & $\mathrm{C}-\mathrm{Br}_{2}$ & 1.7744 & $\mathrm{C}-\mathrm{Br}_{2}$ & 1.849 & $\mathrm{C}-\mathrm{Br}_{2}$ & 2.253 \\
\hline \multirow[t]{7}{*}{$C-B r-B r$} & 34.09 & $\mathrm{Br}_{2}-\mathrm{Br}_{3}$ & 2.6111 & $\mathrm{Br}_{2}-\mathrm{Br}_{3}$ & 3.104 & $\mathrm{Br}_{2}-\mathrm{Br}_{3}$ & 3.522 \\
\hline & & $H-C-B r_{1}$ & 116.58 & $H-C-B r_{1}$ & 117.62 & $H-C-B r_{1}$ & 105.42 \\
\hline & & $C-B r_{2}-B r_{3}$ & 118.60 & $C-B r_{2}-B r_{3}$ & 78.31 & $C-B r_{2}-B r_{3}$ & 92.76 \\
\hline & & $\mathrm{H}-\mathrm{C}-\mathrm{Br}_{2}-\mathrm{Br}_{3}$ & 78.96 & $\mathrm{H}-\mathrm{C}-\mathrm{Br} r_{2}-\mathrm{Br}_{3}$ & -173.3 & $\mathrm{H}-\mathrm{C}-\mathrm{Br}_{2}-\mathrm{Br}_{3}$ & -112.35 \\
\hline & & & & & & & \\
\hline & & & & & & & \\
\hline & & & & & & & \\
\hline
\end{tabular}

a Constrained in the optimization at the value obtained for the centrifugal barrier using the approach outlined in ref. 32. ${ }^{b} \mathrm{MP} 2 / \mathrm{LANL} 2 \mathrm{DZ}$, reference 16. 
Table 7S. Calculated (CCSD(T)//MP2/aug-cc-pVTZ) parameters of species associated with stationary points on the $\mathrm{CHBr}_{3}$ PES used for input to microcanonical rate calculations. All vibrational frequencies (given in $\mathrm{cm}^{-1}$ ) have been scaled by 0.96 . Moments of inertia are given in amu $\bullet \AA^{2}$, energies in $\mathrm{cm}^{-1}$.

\begin{tabular}{|c|c|c|}
\hline $\mathrm{CHBr}_{3}$ & $\mathrm{CHBr}_{3} \mathrm{TS}^{b, c}$ & isomerization TS \\
\hline Energy: $0^{a}$ & Energy: 23,076 & Energy: 21,460 \\
\hline $\begin{array}{c}\text { Frequencies: } 152.0(2), \\
223.1,536.9,678.1(2) \\
1143.7(2), 3076.9\end{array}$ & $\begin{array}{c}\text { Frequencies: } 185.0,460.0,632.0 \\
\text { 784.0, 1160.0, } 3131.0\end{array}$ & $\begin{array}{c}\text { Frequencies: }-484,70.9,173.4, \\
\begin{array}{c}209.3,544.8,650.6,951.3,1194.0 \\
3117.0\end{array}\end{array}$ \\
\hline Active Rotation $(K)$ : & $\begin{array}{l}\text { Active Rotation }(\boldsymbol{K}) \text { : } \\
\qquad I_{c}=13.1\end{array}$ & $\begin{array}{c}\text { Active Rotation }(\boldsymbol{K}) \text { : } \\
I_{a}=283.4\end{array}$ \\
\hline $\begin{array}{l}\qquad I_{c}=801.1 \\
\text { Adiahatic Rotation }(n .\end{array}$ & $\begin{array}{c}\text { Adiabatic Rotation (): } \\
I_{a}=I_{b}=1075.3\end{array}$ & Adiabatic Rotation (): \\
\hline$I_{a}=I_{b}=406.9$ & $\begin{array}{c}\text { Int. Active Rotation (2-D): } \\
\qquad I=407.9\end{array}$ & \\
\hline & Benson $a$ parameter: 0.02 & \\
\hline iso-CHBr $_{3}$ & $\begin{array}{l}\text { iso- } \mathrm{CHBr}_{3} \mathrm{TS} \\
\text { to } \mathrm{CHBr}_{2}+\mathrm{Br}^{c}\end{array}$ & $\begin{array}{l}\text { iso- } \mathrm{CHBr}_{3} \mathrm{TS} \\
\text { to } \mathrm{CHBr}+\mathrm{Br}_{2}{ }^{c}\end{array}$ \\
\hline Energy: 17,450 & $\begin{array}{c}\text { Energy relative to iso- } \mathrm{CHBr}_{3}: \\
5,626\end{array}$ & $\begin{array}{c}\text { Energy relative to iso- } \mathrm{CHBr}_{3}: \\
14,297\end{array}$ \\
\hline $\begin{array}{c}\text { Frequencies: 46.9, 192.4, } \\
195.5,229.7,590.4,648.4, \\
866.4,1166.7,3090.2\end{array}$ & $\begin{array}{c}\text { Frequencies: }-83.4,46.9,193.5 \\
\begin{array}{c}\text { 209.8, 284.2, } \\
\text { 687.2, } 797.6,1146.0 \\
3046.0\end{array}\end{array}$ & $\begin{array}{c}\text { Frequencies: }-49.1,53.0,95.9, \\
\begin{array}{c}\text { 106.5, 282.0, } 308.5,672.3,1106.0 \\
2866.0\end{array}\end{array}$ \\
\hline $\begin{array}{c}\text { Active Rotation (K): } \\
I_{a}=162.7\end{array}$ & $\begin{array}{c}\text { Active Rotation (K): } \\
I_{a}=277.5\end{array}$ & $\begin{array}{c}\text { Active Rotation }(\boldsymbol{K}): \\
I_{a}=59.2\end{array}$ \\
\hline $\begin{array}{c}\text { Adiabatic Rotation (⿹: } \\
I_{b}=I_{c}=986.6\end{array}$ & $\begin{array}{c}\text { Adiabatic Rotation (⿹): } \\
\qquad I_{b}=I_{c}=1730.7\end{array}$ & $\begin{array}{l}\text { Adiabatic Rotation (): } \\
\qquad I_{b}=I_{c}=1599.6\end{array}$ \\
\hline
\end{tabular}

a Energies relative to $\mathrm{CHBr}_{3}$ minimum unless noted. ${ }^{b}$ Gorin transition state. ${ }^{c}$ The moments of inertia were calculated from the centrifugal maximum using the procedure outlined in ref. 32 . For the iso- $\mathrm{CHBr}_{3}$ transition states, the structures were optimized at these maxima. 
Figure 1S. Upper panel: Microcanonical rate constants for $\mathrm{CF}_{2} \mathrm{Br}_{2}$ decomposition as a function of energy. Lower panel: Yield of the molecular (isomerization) channel as a function of energy, where a unit quantum yield for the formation of molecular products following isomerization has been assumed. The dotted line marks the average energy of the experiments described in ref. 34 .
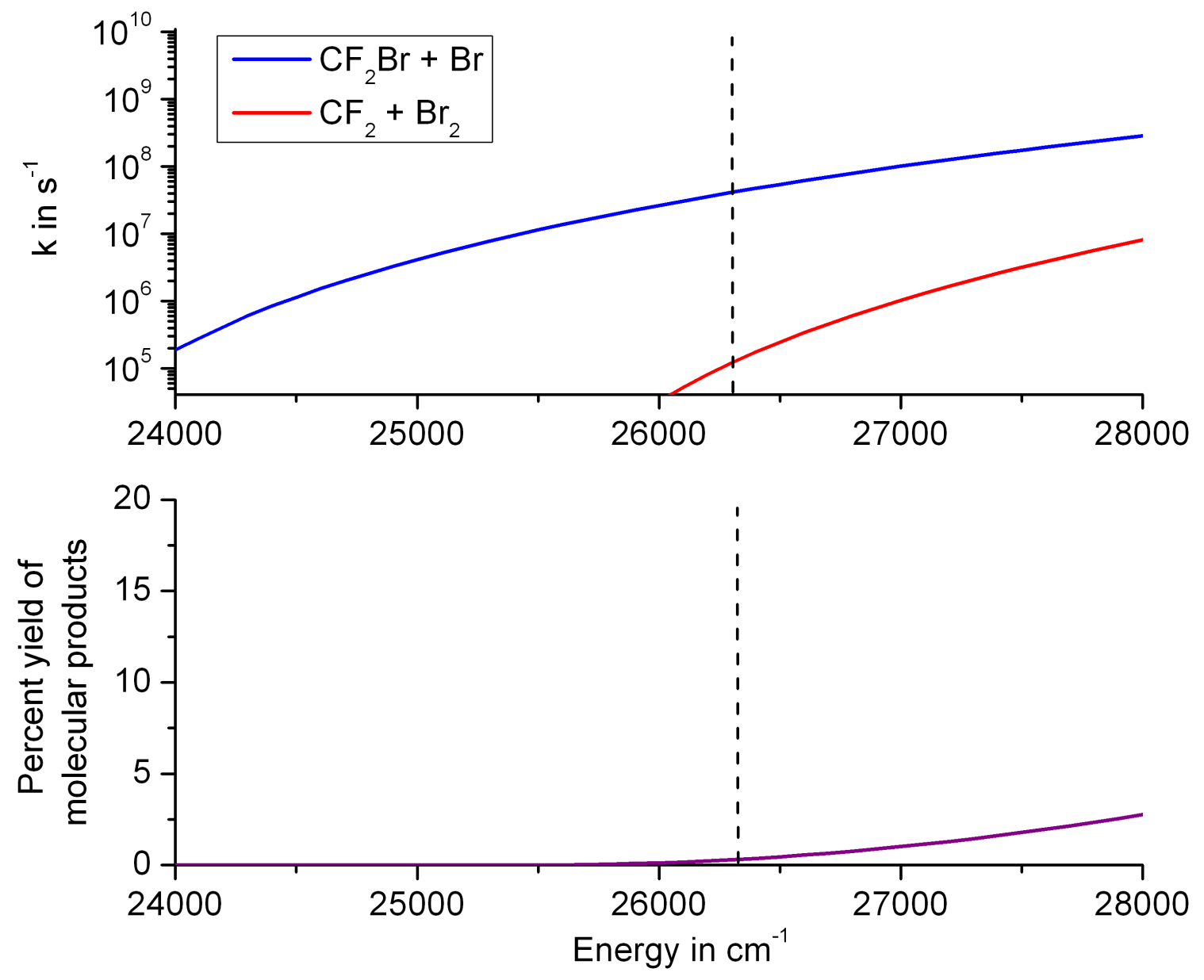
Figure 2S. Upper panel: Microcanonical rate constants for $\mathrm{CHBr}_{3}$ decomposition and isomerization as a function of energy. Lower panel: Yield of the isomerization channel as a function of energy.
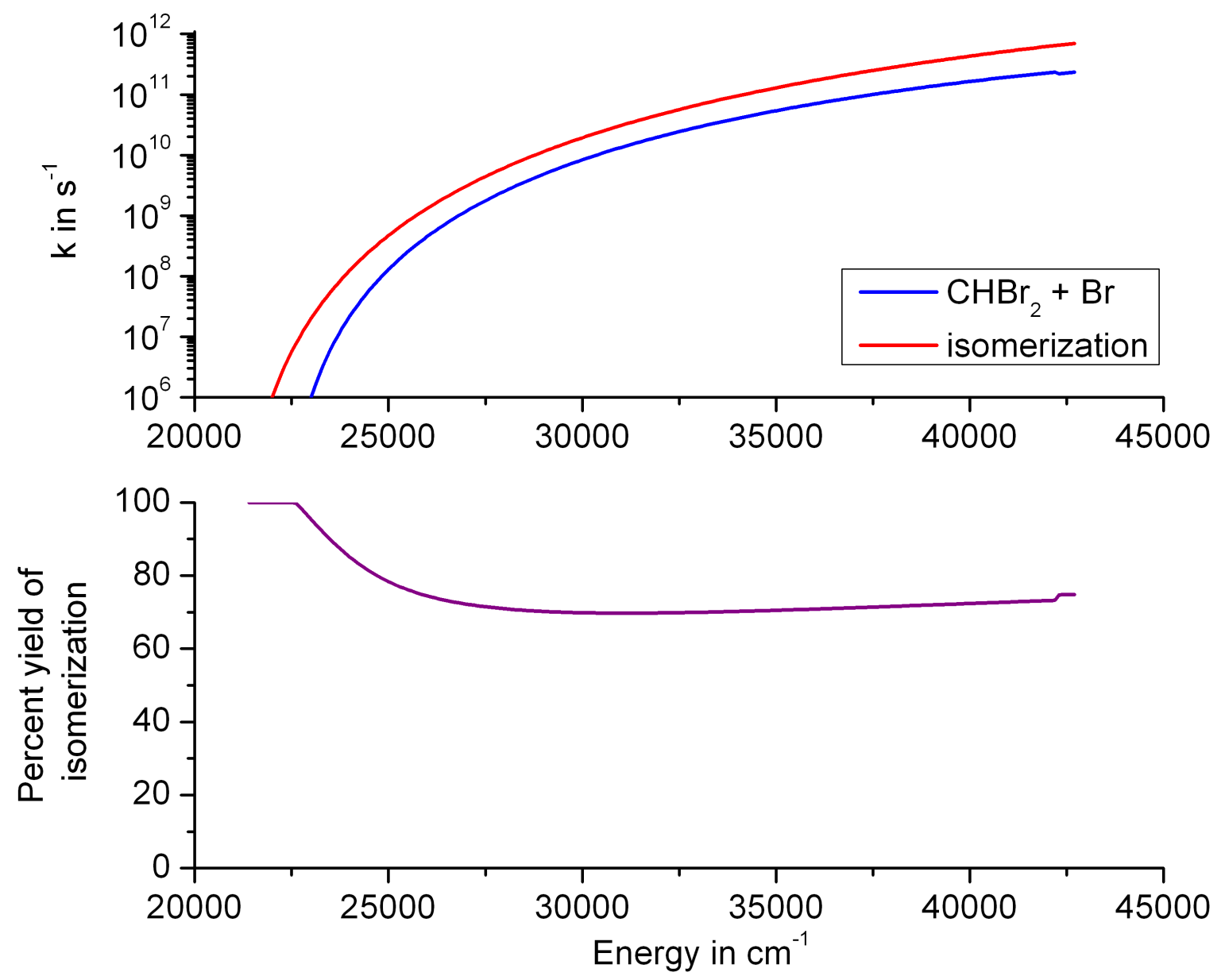
Figure 3S. Upper panel: Microcanonical rate constants for iso- $\mathrm{CHBr}_{3}$ decomposition as a function of energy. Lower panel: Yield of the molecular channel as a function of energy.
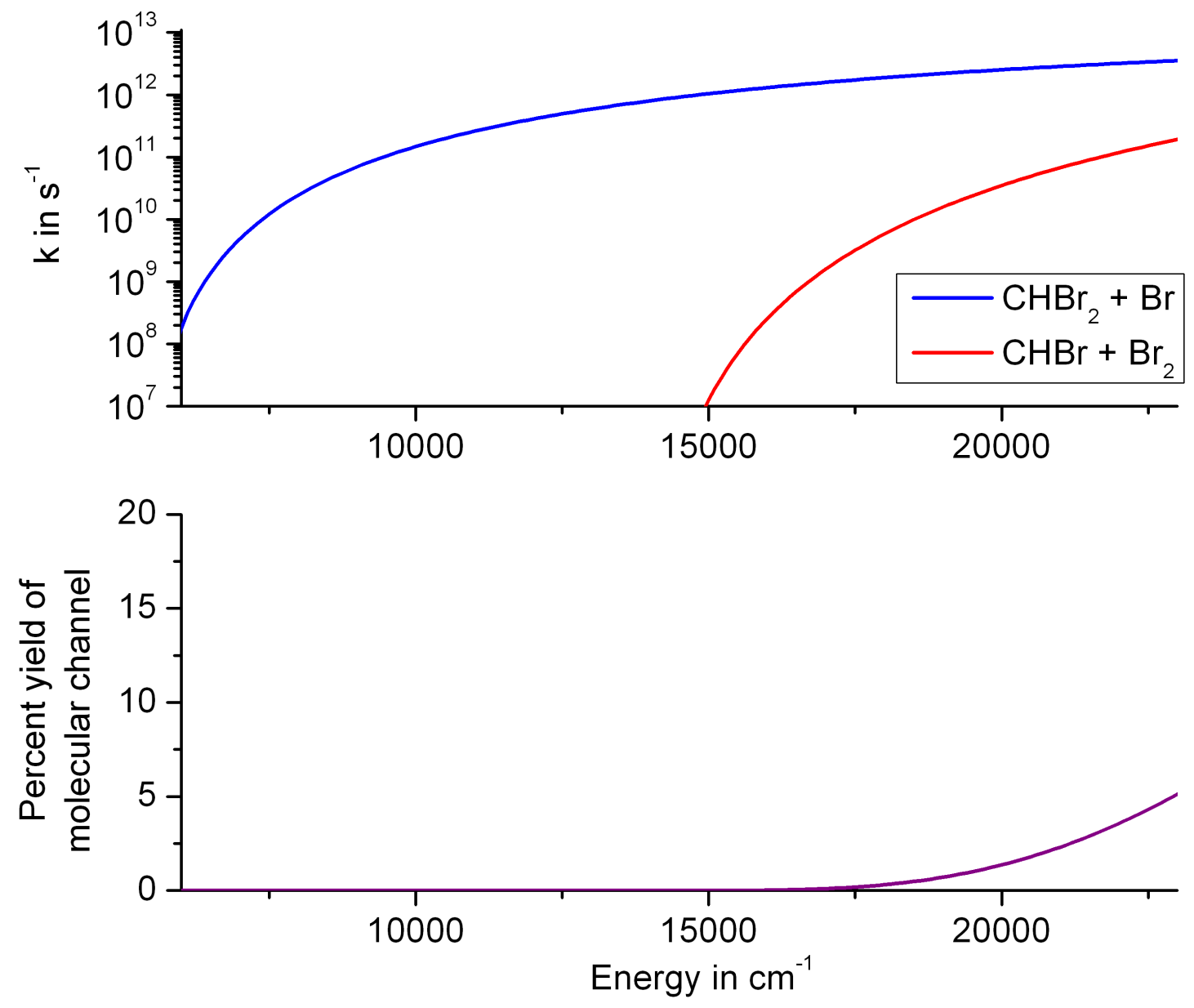